ALEŠ KOMÁR

\title{
THE MILITARY TRAINING AREA RALSKO AND THE ARMY
}

A. Ko már: The Military Training Area Ralsko and the Army. - Geografie - Sborník ČGS, 103, 3, pp. 320 - 330 (1998). - The article in its introduction deals with the problem of the former Military Training Area at Ralsko in the Czech Republic and its recent changes - the nature and landscape protection under the auspices of the Ministry of Defence and military administrations in the MTA, and deals with the consequences of the withdrawal of corps and discusses the damage caused by military training to the nature, soil and groundwater. In the conclusion the article evaluates the topical aspects of the area reutilisation.

KEY WORDS: military training area - environmental security - environmental damage.

\section{Introduction}

The military region Ralsko is known as the Military Training Area (MTA) Mimon. From the mid-1970s to the end of the 1980s it was one of the most intensively used military areas in the Czech Republic.

Regarding the recent period, when the devastation of the environment in some parts of this country reached almost disasterous dimensions, it seems to be hard to imagine that it was the army which, as the administrator of the area, managed to keep the environment in a good state even when intensively used by foreign troops. Scientific research conducted by the Czech Institute for Nature Protection, the Czech Environmental Institute, the Botanical Institute at the Academy of Sciences (AV) and the Masaryk University in Brno on the territory of the former military region Ralsko, abandoned by the army (and the Central Group of Troops, CGT) in 1992, prove that the nature and landscape in the military area is almost untouched or only slightly changed. The reason is clear - the military training area was free of industry and use for recreational purposes. In the previous period the army fought against the spread of uranium mining, the building of sludge beds and nuclear power infrustructure and making the area, including the Ralsko castle ruins and water resources, open to tourists and for recreational purposes. On the contrary, despite certain fears of violating the then military cooperation, the Defence Ministry agreed to join the Ramsar agreement as well as a supplementary change in this international protocol which concerned the Ralsko area directly, without conditions. Thus it expressed the agreement with the protection of swamps, which are of international importance, particularly for being the biotopes of water birds. BřehyněPecopala (a national nature reserve established in the military area by the Inspection Ministry, MKI, on September 26, 1967, along with other reserves - the Hradčanské Ponds and Ralsko) was later included in the biogenetic network of the Council of Europe. The national nature reserves Břehyně- 
Pecopala, the Novozámecký pond, the Hradčanské ponds nature reserve and the national nature park Swamp are the subject of research within the Programme of Europe for the protection of biological diversity.

\section{From the history of the military area}

The former military area was used by three main users. The military use, under the commander of the MTA Mimoň, was of primary importance. The evacuation of the area after World War Two, its size and considerable remoteness from large communities, but mainly its closedness from the geomorphological, cultural and administrative point of view and its location in the country, met the needs of the state defence. The slightly undulating surface of the Bezděz plateau, a suitable representation of land cultures covered by forest masiffs and water resources, seemed to meet perfectly the need for extensive military training in the early 1950s. After the establishment of the Military Training Area in 1950 training was more or less extensively led by the Czechoslovak Army. After 1968, on the basis of a demand raised by the Soviet Army Central Group of Troops (CGT), an agreement on the common use of the area was concluded with the former Czechoslovak Peoples Army (ČSLA). The military base of the 1st Army and CGT was subordinate to the commander of the Western Military Circle in Tábor. As demanded by the Soviet command, the education and training base was gradually modernised, including the construction of a modern airport on the site of the former one built for the Luftwafe near the village of Hradčany in 1940. The Czechoslovak army gradually left the area as it stopped using it for training in the mid-1980s. The intensity of training was much higher than planned at the time the MTA was established. It limited the economic use of the area, but quantitively it touched only $10-15$ percent of the area. The other parts of the area are in a considerably good state. We can find very stable and original communities and ecosystems here, which show what the nature could have looked like if it were not for negative human activities. Besides the above-mentioned airport and its infrastructure (particularly aircraft fuel storage facilities), the environment was also polluted by the barracks (by the production of industrial and household waste, oil industry, arms and military equipment cleaning plants and the pollution of the land and underground water by oil and chlorinated hydrocarbons). Field training has affected tank tracks, roads and shooting ranges including dropping areas rather than the places destined for training as strategic attack positions. More damage was done to the vegetation (forests) around the air shooting range, that is in the bombed area (liquidation of the growth and splinters in nearby trees). Simply put, over the past twenty years of military use this precious area suffered a lot from the military activity, in some cases even to the pont of irreversibility. A special problem also consists in the unexploded ammunitition which has not been discovered yet. We have to point out that no chemical substances (herbicides, insecticides and other pesticides) were used here to keep the training area passable and that a lot of water protection zones have been created here.

The commander of the Military Training Area was responsible for the use of 4,501 hectares of land, 47 hectares of which were covered by water and 289 hectares were built-up areas. In the narrow sense of the word, the area, registered as sector 21 , is now called a military training area within a broader 
military region. It is also worth noting that, according to official data, the total value of military training facilities and buildings at the time the area was closed equalled about 176 million crowns and consisted of more than 1,000 houses and 2,000 flats.

The economic activity, run by the Vojenské lesy a statky Mimoň (VLS) state-owned company, set up by the Defence Ministry, focused on forestry and farming. The most important was timber production, which, among other things, took into account the fact that the area lay in a protected zone where underground water was accumulating. Forests covered 18,362 hectares. We should also note that even though farming was among marginal activities, VLS was the most effective among the 11 companies of its kind of that time. The Mimon plant employed about 700 workers. Its economic output totalled 130 million crowns, fixed assets in residual price equalled 180 million crowns. A total of 80,000 cubic metres were cut, 6,100 cubic metres of timber were produced and 230 hectares of land were aforested. The agricultural market production amounted to 53.3 million crowns. Milk supplies totalled 6.2 million litres, slaughtered meat supplies 632 tonnes and grain harvest reached 5,700 tonnes. The farming land covered 887 hectares, 711 of which was arable land. In addition, 374 hectares of the training area were also used for farming. Altogether 1,261 hectares were used for agriculture (data from January 1, 1991), practically without a great use of chemicals. There were only minor problems with polychlorinated biphenyls (PCB), which were mainly the result of using coating compositions for the protection of fodder conservation facilities. At the end of the 1980s, farming and forestry fully respected the opinions on eco-friendly methods. This resulted in a change in the approach towards the decontamination and recultivation of the training areas, in the way of wood-cutting, soil reclamation and pond renewal, which tried to preserve the environmental stability of the training area as a whole. The reclamation of meadows near Hradčany, for example, is given by scientists as an example of a positive way of caring for the landscape.

The general administration according to the law on military regions and administration of land protection, area planning and construction according to related laws were performed by the Ralsko military region administrator based in Mimon. We are glad to say that the administration headed by an officer carried out this task in the 1980s until the area was transferred to a civil administration excellently. The army did not relinquish environmental protection, mainly land, water, nature and landscape protection, but was able to push through the laws and thus prevent the devastation of the territory until it was transferred to civil administration. The fact that there were not many civilians accompanying CGT and living nearby as it was in the case of the Military Training Area Mladá was a certain advantage. Special attention was paid to small protected areas, set up according to a related law, to environmental and cultural protection of certain places, according to area planning materials, to delimitation and use of land for military purposes, to observation of environmental protection principles during military training and to environmental regulations, which were a part of the statutes of the military training area.

Public utilites of the Ralsko area included two nursery schools and three food shops. The area was inhabitated by 554 people living in five communities (Boreček - 59 people, Hradčany 160, Náhlov 103, Dolní Krupá 55 and Ploužnice 168) and four lone houses outside villages (nine people). The 
civilian facilities also included the Uranové doly Hamr na Jezeře state-owned uranium mining company and the Veterinary Sanitary Institute.

\section{Environmental administration}

The Defence Ministry issued a lot of regulations on nature protection and state administration. It is worth recalling them - they belonged to the first instruments of environment protection, mainly in the form of securing care by good managers. In the mid-1980s they started focusing openly on the environment, with the aim of protecting its components in harmony with the valid laws. The foundations of a new branch of military science - military ecology - were gradually laid down.

The first task was to find out and describe the real state of the area (through automated registration, inventorying and areal surveying) to propose the proper protection of the areas used in various ways (delimitation in the economic and training part of the area, area planning, decontamination and recultivation, environmental regulations) and to ensure prevention (environmental protection principles and the revision of the land fund protection and use). In this way the negative influence of the military use on the Ralsko Military Training Area was reduced. The following is a chronological list of the most important materials issued by the Defence Ministry, which shows its environmentalist efforts: Regulations for the Registration of the Lands In the Administration and Use of the National Defence Ministry (1983); Automated Registration of Military Lands - project No.7 7205 (1984); Regulations for the Creation of Land Maps of Military Regions (1984); Instructions for Company Registration of Land at VLS Organisations (1985); The Definition of Valuated Environmental Units of Land and Farming Land Protection (1985); The Use and Protection of Land In the Competence of the National Defence Ministry (1986); Decontamination and Recultivation Measures in Military Training Areas (1986); The Protection of Land and Water against Negative Effects of Harmful Substances (1986); Regulations for Area Planning in Military Training Areas (1987); The Principles of Thematic Inspections and Regular Revisions of the Land Fund Management (1987); Methodical Instructions for Monitoring of Land in the Competence of the Federal Ministry of National Defence (1989); Regulations for the Protection and Use of Farming Land in Military Training Areas (MTA) (1989); Methodical Instructions for Special Use of Overburden of the Cultural Layers of Land (1989); The Principles of Environmental Protection in Military Training Areas (MTA) 1990); The Principles of Environmental Protection in Agricultural Production and Forestry and the Operation of Agricultural Companies (1990).

Significant materials, which describe the state of the territory of the former MTA are area plans, describing it from a wider point of view as a large area, focusing on some important places on the level of zone plans. In the case of this MTA only the first phase of plans was completed, that is the research and analysis of the Ralsko Military Training Area (MTA Mimoň), including comments on the first phase and creation of so-called military economic principles for the use of the military area. Subsequently, in 1990 an area plan was designed. However, a discussion on the plan did not follow as the military administration of the area ended on December 31, 1991. These materials are very valuable as they in fact record the last phase of development of the area 
for military use before the withdrawal of troops. They describe the training grounds, education and training facilities, accommodation capacities, transport infrastructure, water resources and their protection zones, production plants, forestry and farming land, the population and its settlement and so on. The area plan followed a land map of the area in scale 1:5,000, which is clear from the above list of documents. The map records even non-secret construction sites. Local military administration of buildings also kept a project register of permitted constructions (or the dead archive of KVUSS Litomerřice). Very precise delineations of the outlines of all buildings and facilities of that time can be provided by foreign experts, on the basis of data acquired by the remote research of the Earth.

\section{The end of training in the area}

Military training in the area stopped on the recommendation of an environmental protection inspection, made by the Inspection Ministry. According to governmental decision No. 541 from September 5, 1991, the area was transferred to a general interior administration of the local district office on January 1, 1992. The governmental decision also named explicitly the plot numbers of lands which were to remain under the management of the VLS company or the Defence and Interior Ministries (for example the lands and facilities of the Bělá pod Bezdězem refugee camp). VLS was assigned the task of eliminating the consequences of military training through the clearance of training facilities, primary reclamation of the farming and forestry land and liquidation of damage to water streams, waterworks and water roads, in harmony with the interests of environmental protection and landscape creation. The Defence Ministry was to draft individual plans for the transfer under civil administration, which included environmental description of the military region.

Problems concerning the abolition of the military region and the damage caused by it were solved by the Mixed Czechoslovak-Soviet Commission for the Enviornmental Aspects of the Withdrawal of Soviet Troops from the ČSFR Territory. The commission was established at the Defence Ministry within the Administration for the Withdrawal of Soviet Troops from CSFR. From 1992 the work was carried out by the Office for Resolving the Consequences of the Withdrawal of Soviet Troops at the Federal Environment Ministry (FVŽP), which focused on liquidating the land and water pollution by oil substances. The Defence Ministry fulfilled special tasks assigned by military environmentalists (the environmental service) or by military construction offices (when removing unpermitted constructions).

\section{Problems with old environmental burden}

Regarding the fact that MTA Mimoň was used exclusively by the Soviet Armys CGT, the environmental damage described below is not connected with the activity of the Czechoslovak Army. The calculation of the total environmental damage caused by the stay of troops was the responsibility of the Mixed Czechoslovak-Soviet Commission for the Environmental Aspects of the Withdrawal of Soviet Troops from the CSFR Territory, set up in March 1990. The extent of damage was measured by the Botanical Institute at the 
Czechoslovak Academy of Science (ČSAV) (geobotanical research), the Czech Institute for Nature Protection (ČUOP) (protected areas), the Laboratory of Remote Research of the Earth at the CUOP (vegetation development), the Research Institute for the Reclamation and Protection of Soil (damage and destruction of soil). Hydrogeological research was conducted by the Stavební geologie Praha company (pollution of land and underground water).

\section{Damage to nature caused by training}

Serious damage to particularly protected nature areas was done in the national nature reserve Hradčanské Ponds, where damage to the pond dike and permanent lowering of the water level weakened the population of the protected calla-lily, and in the national nature reserve Ralsko, where the locality of the protected Alpine aster was destroyed by treading, the collection of scree and fire. Research has revealed that despite extensive damage to natural ecosystems and ecosystems close to nature, a great part of the territory is of great natural historical and general environmental value. It was decided to establish 18 protected areas in the Ralsko Hilly Land. These are Ralsko (the highest peak), the Vranovské skály rocks, Lipovec (basalt scree), the meadows near Ploučnice, Mešné (peat pine woods), Jelení vrch, sand down over the Černý rybník pond, the peat-bogs Cerný rybník, Ostrý and Děvín, Široký kámen, Divadlo, buried podsols under Černá Novina, the peat-bogs Děvínská louka, Chrastný, the transition moor near Kunratice, the Kavčí skály rock (stones), flowery pine woods under Černá novina and Stohánek.

Changes in the MTA landscape were evaluated according to surveying aerial photographs in scale 1:10,000 in the initial state in 1968 and the final state in 1991 (the Dobruška Military Topographical Institute). The evaluation concerned the occupation of farming and forestry land, land erosion, the damage to the soil-protecting cover by military vehicles and shooting, endangering of forests by military activity and the identification of waste dumps. The summary of changes in the surface cover shows that forests, particularly the coniferous ones, and the farming land cultures declined most, while the construction (including that of the airport and roads), grass growth and devastation caused by uranium mining (277 hectares) saw an increase, along with dead forests caused by fire ( 55 hectares) and an increase in leafy foliage, dumps and the water area. Military vehicles damaged about two thirds of the MTA (in the narrow sense of the word MTA).

The calculation of the damage to nature was based on Phytocoenological materials on biological decontamination of the MTA worked on in the past (Kopecký a kol. 1985) and on the current analysis of floristic and vegetation conditions made on the basis of research conducted immediately after the withdrawal of troops from the area by the ČSAV Botanical Institute at Průhonice. Striking phenomena on the abandoned territories include macrodisturbances as a result of a typical management of training areas, the disintegration of types of vegetation present there for centuries and the expansion of invasive species of weed. The biological and production potential of the landscape was preserved only in some parts, for example in the meadow Ploučnice, Hradčanské stěny, in the summit parts of Ralsko and elsewhere, but the potential can be renewed without major problems at other places as well. 
Before the creation of the Military Training Area there was a cultural landscape predominated by forests (about 75 percent of the area), mainly coniferous monocultures of pine trees. Arable farming land covered about one fifth of the area. Training grounds were set up on fields, and in the past twenty years also on the site of forests (for example the Vrchbělá training grounds and the Hradčany airport). Tree-cutting and fires reduced the forests, which cover about 73 percent of the area, by 1,547 hectares.

Human influence was specific - the vegetation was either mown irregularly or not at all, nor was it fertilised. The surface of the soil was densely and permanently hurt. This gave rise to a mosaic of growths of herbs, bushes and trees, prevailing in various ways in successive periods of time. Limited and irregular eroding of the turf and open wounds destroy the original grass community, but it also compensates for the effects of nonmowing. This helped preserve the whole composition of species of original growths, and the training grounds seem to be a resource of a genofund of species. Cultural pine woods were strongly damaged around military camps (thinning, dumps, trenches). As a result of eutrophication of water and synanthropic communities of herbs (for example knotgrass - dry uncovered soils, mainly regular roads on the training grounds). A massive spread of invasive species can be seen as a result of the lack of care of the training grounds. The accumulation of old unmown grass also enriched the soil with nutrients. The aggressive lupine, which, moreover, enriches the soil with nitrogen, has also widely spread, along with common broom. After the end of military use it destroyed completely and irreversibly the social structure of enclaves of the former MTA which have been establishing here for centuries.

After the coming of agressive invasive species (for example nettle and white sweetclover) timber species start dominating here (birch, raspberry shrub, willow and others), which signal an irreversible change in the original vegetation. Calculation (according to the price list) could be made for damage to only four protected species at three places (the south edge of the Kurrivody village, Vrchbělá, the bank of the Vavroušek pond and Hradčany). It reached over two million crowns.

A special kind of damage results from interferences that prevented the economic use of the vegegation (terrain obstacles - furrows, craters, trenches and so on, and self-seeding of timber species), which is connected with uncountable damage to the landscape (deforested areas, areas damaged by shooting and fires, unsuitably located buildings, changes in terraine, dumps around military camps and so on). This also includes damage caused by intensive uranium mining in the northwestern part of the area.

\section{Damage to soil on the training grounds}

The damage caused to soil included destruction, mechanical damage, degradation and possible contamination with risk elements. Research observed both the horizontal and vertical damage to the natural and cultural soil cover. It was conducted at various places, including the training grounds, the barracks, camps, storage facilities, the airport, the target grounds, motor roads, tank tracks and other roads, waterways, firingpositions, land constructions as well as on the farming land. As to risk elements, the research observed mainly the amount of $\mathrm{As}, \mathrm{Be}, \mathrm{Cd}, \mathrm{Co}, \mathrm{Cr}, \mathrm{Cu}$, 
$\mathrm{Hg}, \mathrm{Ni}, \mathrm{Pb}$ and $\mathrm{Zn}$. The characteristics of the damage caused by military training to soil are following:

- Rearrangement in strata, superimposing and mixing of lower layers with the original humus horizons. The terrain is very uneven, containing craters and trenches (terrain arrangements) of various depth and size, occuring with various density.

- Hydromorphic development of soil in depressions with stagnant rain water. Depressions of anthropogenous origin give rise to pseudogley and stagnogley soils, planted in some parts of the relief by hydrophytic vegetation.

- Erosion, both superficial and furrowed, mainly where the sod layer of soil has been destroyed by frequent crossing of military vehicles. Only uneven dead subsoil horizon remains where humus horizons are washed away.

- Decrease of land resources as a result of investment construction. Such places are irreversibly lost for other use as their reclamation is expensive.

- Amount of splinters and fragments of shells and grenades, empty cartridgecases and unexploded ammunition.

- Spread of self-seeded and spontaneous vegetation, which at present has grown into bushes and trees.

- Combination of all the above-mentioned kinds of damage on various levels of quality and quantity.

The soil damaged on various levels and the undamaged soil create a diversified mosaic, so the damage to the land resources can be quantified according to degrees (expressed in percents). The relatively undamaged areas are those used for farming, as mentioned above, and partly as training grounds. The medium degree of damage is recorded on most of the intensively used training grounds, mostly as a result of terrain erosion due to a dense network of roads, trenches and other minor changes in the terrain. The highest degree of damage has been done to grounds with shooting ranges, airports, mounds, earthwork and other things. A specific phenomenon in Ralsko is sand quarrying, which is considerably spread and chaotic. The damage to soil caused by military activities can be considered serious regarding the character of soil on the training grounds (extremely light to light soil). Arenous regosols, podsols and sod-podsolic soils are very sensitive to the liquidation of the vegetation cover and damage to the soil profile, particularly the humus horizon. The soils are then prone to water erosion, which in Ralsko occurs even on places which are not so sloping. Farming land consists of medium-heavy brown soils and sod-podsolic soils, and partly of lowland meadows, depreciated by permanent wet. Military use damaged a total of 2,842 hectares of land. The damage accounted for 25 up to 80 percent of the area and has been calculated at more than 63 million crowns.

As to the contamination of soil with risk elements, the concentration of plumbum measured at the airport was above the limit. Other elements which exceeded the level of natural amount but were still below the permited limit included arsenic, found at three places (training grounds), beryllium, found at two places (the shooting range and the target area) and zinc, found at one place, out of 58 places where samples were collected. Repeated military use, mainly military vehicles, did not have any fundamental influence on the concentration of plumbum and cadmium in soil. 


\section{Soil and water decontamination}

The work on discovering the degree of contamination of underground water and soil was the most difficult. Hydrogeological research at nine selected places (Hradčany, Hvězdov I, Hvězdov II, Jabloneček, Jezová, Kuřivody, Stráž pod Ralskem, Svébořice and Vrchbělá), in financial terms considered to be the claim of the Czech side, cost 14.6 million crowns. The hydrogeological clearance (decontamination) itself amounted to 370 million crowns. We are glad to say that the pollution was removed and that decontamination work is now being carried out only at the Hradčany airport, which is one of the most oil-polluted places in the Czech Republic. The contamination, mainly by aircraft oil and diesel, affected mostly the soil above the underground water level. Concentration of oil hydrocarbons exceeding 2,000 miligrammes per kilogramme of soil can be found on almost 30 hectares of land, on the site of former fuel storage facilities which were built on sandy ground without being secured against leakage during storage and handling. The total amount of oil substances above the underground water level reached 6,500 tonnes.

The former military area lies in the Bohemian Cretaceous Basin, which is significant from the point of view of water resources. It is a part of a protected zone with accumulation of underground water and of a region which is the most important as to hydrological balance (464 - Horní Ploučnice). The surface of underground water lies at a depth of 3 to 18 metres under the terrain and the power of the collector with free surface of underground water moves betwen 67 and 75 metres. The stream of the underground water goes towards the drainage basin of the Ploučnice river.

The "in situ" decontamination from oil floating on the underground water level started in 1989. As its effectiveness was decreasing, a method of venting started to be used in 1993 . The venting field covering 4.81 hectares consists of 353 drill holes going to the depth of the undeground water surface of $4-8$ metres, from where the soil air is exhausted by 34 exhaust fans. After the completion of the venting field in 1995 a more effective method of controlled bioventing has been applied. This ensures a permanent supply of oxygen, an optimal supply of nutrients and inoculation of bacteria degradating oil hydrocarbons. At the same time the oil product from the underground water level and the contaminated water is being removed. By the combination of the above-mentioned methods the concentration of oil substances should reach a limit of 1,500-2,500 miligrammes per kilogramme and the decontamination is expected to be completed before the year 2000 .

\section{Conclusion}

Previous forecasts for types of management in the former Military Training Area did not materialise. The exploitation type, which consisted in the adaptation to the neighbourhood use of landscape, as well as the progressive type, following controlled landscape management, which was the best for a long-term preservation of the landscape balance, were not applied. The conservative type of management was applied partly. It consisted in natural development of the landscape with only minimal human interference, which is the way the MTA was used before 1968. Besides the work carried out at present (such as bomb disposal, hydrogeological decontamination and forest work), it is also necessary to materialise concrete measures which will speed 
up the elimination of the impacts of insensitive behaviour. These measures include planting mixed woods (oak woods), aforestation of some places, regular mowing and revitalisation of meadows, reconstruction of dispersed vegetation, revitalisation of hydrological conditions the Hradčanské Ponds, renewal of settlements, declaration of protection areas and so on. The gradual use of the landscape should not consist only in minor and single privatisation bids. They should be based on a project, taking into account the whole of the territory and its surroundings, and including both minor and major bids within a complex exploitation of the system use of the area. A cooperation on the project of a NATO/CCMS pilot study has shown a way to creating a marketing project of conversion.

\section{References:}

HERČÍK, F., PROKŠOVÁ, S. (1997): Aplikace ventingu a bioventingu při sanaci letiště Hradčany. KAP News, III. čtvrtletí, Praha, pp. 1-3.

HUSÁKOVÁ, J., VĚTVIČKA, V. (1991): Posouzení problematiky ekologických škod způsobených sovětskou armádou ve VVP Ralsko, zvláště pak na chráněných částech pŕírody z hlediska botaniky. Botanický ústav ČSAV, Průhonice, $39 \mathrm{p}$.

KOMÁR, A. (1989): Územní plánování ve vojenských újezdech. Týl ČSLA, 39, No. 5, pp. 4647.

KOMÁR, A. (1992): Chráníme přírodní prostředí? Úkoly a vyhodnocení prověrky. EL, Vojenský ekonomicko-ekologický časopis, 1 , No. 5, pp. 25- 30.

KOMÁR, A. (1993): Vojenský újezd Hradiště. Sborník CGS, 98, No. 2, NČGS, Praha, pp. 7586.

KOPECKÝ, K. et al. (1985): Fytocenologické podklady k biologické asanaci vojenských výcvikových prostorů Vyškov, Boletice, Jince, Ralsko a Mladá. Závěrečná výzkumná zpráva, Botanický ústav CSAV, Průhonice (depon. MO), 517 p.

NOVÁK, P. et al. (1991): Zpráva o škodách, způsobených Sovětskou armádou na půdním fondu ve vojenských výcvikových prostorech Mladá, Ralsko a Libavá. Výzkumný ústav meliorací a ochrany pưdy, Praha, 43 p.

PIVNIČKOVÁ, M. (1997): Ochrana rašelinových mokřadů. Agentura ochrany přírody a krajiny ČR, Praha, 32 p.

\section{Sum m ary}

\section{THE MILITARY TRAINING AREA RALSKO AND THE ARMY}

The Ralsko military land (Mimoň military training area) was until the late 1980's one of the most intensively used military training areas in the Czech Republic. The former military area was used by three main subjects and its primary usage was for defence purposes.

The commander of the military training area was responsible of usage of 4,501 ha of lands. According to the official data, the total value of existing military training equipments and buildings was, at the time the military land was closed, about $176 \mathrm{mil}$. Kč and included, among others, more than one thousand buildings and two thousand flats.

Economic activities were provided by the state establishment Military forests and farms Mimon. Wood production was essential; the forests covered an area of 18,362 ha. The agriculture land area covered 887 ha, out of them 711 ha of arable land. Other 374 ha of soil from the training sector land were also used for farming purposes, so that in total 1,261 ha were used for agricultural production (by the 1st of January 1991), practically all of them without using larger quantities of fertilizers.

The general internal administration according to the law on military lands, and the administration relative to soil protection, territorial planning and building regulations according to respective laws were ensured by the military land administrator of the Ralsko military land with his seat in Mimon. Special attention was paid to the protection of smallarea territories, established according to the respective law, to the protection of localities 
meriting a special attention from the ecological and cultural viewpoint as it was settled by the territorial planning documentation, to the delimitation and land usage for military purposes, to observation of principles of environment protection during the military training and to ecological operational regulations which were a part of the military training area statute.

In the military land there lived in total 554 inhabitants in five settlements (Boreček 59, Hradčany 160, Náhlov 103, Dolní Krupá 55, Ploužnice 168 inhabitants) and in four lone houses (9 inhabitants).

A series of regulations were published by the Ministry of Defence with a view to ensuring nature protection and state administration. Bases of a new military branch - military ecology - were progressively laid, the most important of them being the Usage and protection of soil in the sphere of activities of the Ministry of National Defense (1986); Sanation and recultivation measures in military training areas (1986); Soil and water protection against negative impacts of noxious substances (1986); Directives for territorial plans in military training areas (1987); Directives for soil protection and usage in military lands (1989); Principles of environment protection in military lands (1990); Principles of environment protection in agricultural and forest production (1990).

An important document is the draft of territorial plan of the military training area from the year 1990. According to the decision of the government of the Czech and Slovak Federal Republic from the 5th of September 1991, No 541, the military land was transferred, on the 1 st of January 1992, to the general internal administration of the respective district authorities.

In spite of the negative impacts of military training, the former military area is rich in plant communities. In total, 2,842 ha of soils (qualified as other areas) were damaged by military activities. The percentage of damaged areas mainly oscillated between 25 and 80 . Damages to soils were estimated to reach more than 63 mil. Kč. A way to introduce a conversion marketing project was shown by the co-operation within the project of NATO/CCMS pilot study.

(The author is with Land Forces Military College, 68203 Vyškov.)

Arrived at the editors office on April 3, 1998

Recommended for publication by Václav Poštolka and Zbyněk Ryšlavý 